\title{
Augmentative and Alternative Communication in Ventilated Patients: A Scoping Review
}

\author{
Comunicação Alternativa e Aumentativa em Doentes Ventilados: Scoping Review \\ Comunicación Aumentativa y Alternativa en Pacientes Ventilados: Scoping Review
}

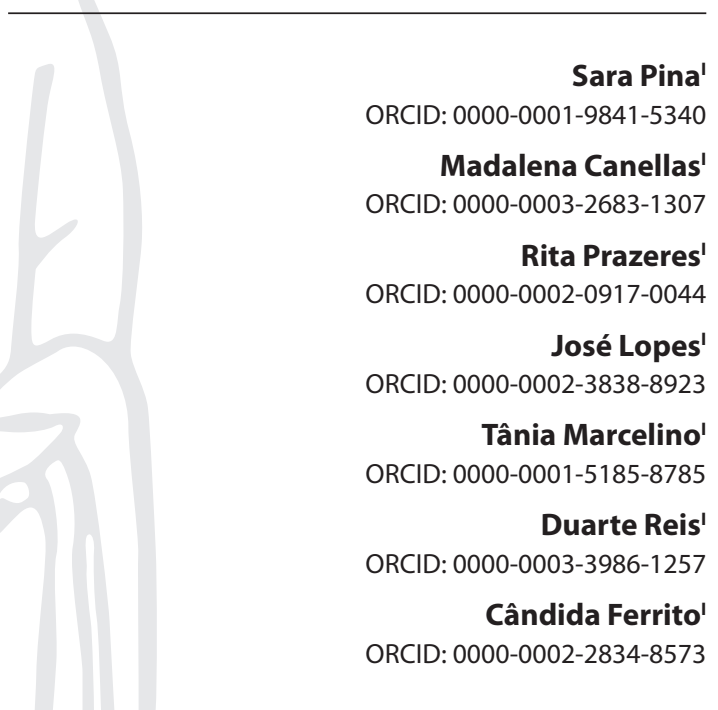

'Universidade Católica Portuguesa. Lisboa, Portugal.

How to cite this article:

Pina S, Canellas M, Prazeres R, Lopes J, Marcelino T, Reis D, et al. Augmentative and Alternative Communication in Ventilated Patients: A Scoping Review. Rev Bras Enferm. 2020;73(5):e20190562. doi: http://dx.doi.org/10.1590/0034-7167-2019-0562

Corresponding author: Sara Fernandes de Moura Pina E-mail:mf.sara@hotmail.com

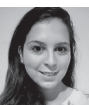

EDITOR IN CHIEF: Dulce Aparecida Barbosa ASSOCIATE EDITOR: Antonio José de Almeida Filho

Submission: 07-27-2019

Approval: 01-10-2020

\section{ABSTRACT}

Objectives: to map the benefits of Augmentative and Alternative Communication in ventilated adults in Intensive Care Unit and identify strategies used. Methods: a Scoping Review was carried out according to the Joanna Brigs Institute Protocol. The research question was: "In adult patients ventilated in Intensive Care Units, what are the benefits of Augmentative and Alternative Communication?". An article research was carried out at PubMed, EBSCOhost and B-On databases. It was held between October and November 2018, from 2013 to 2018, in Portuguese and in English. Results: 61 references were obtained. After selection according to the inclusion criteria, 7 articles were analyzed. Conclusions: studies enunciate Augmentative and Alternative Communication as a strategy to enhance communication, describing methods and tools. There is no agreement on the most effective tool.

Descriptors: Augmentative and Alternative Communication Systems; Artificial Respiration; Critical Care; Nursing Care; Nursing Care; Scoping Review.

\section{RESUMO}

Objetivos: mapear os benefícios da Comunicação Alternativa e Aumentativa em adultos ventilados em Unidade de Terapia Intensiva e identificar estratégias utilizadas. Métodos: realizada uma Scoping Review segundo o Protocolo Joanna Brigs Institute. A questão de pesquisa foi: "Em doentes adultos ventilados em Unidades de Cuidados Intensivos, quais os benefícios da Comunicação Alternativa e Aumentativa?". Realizada pesquisa de artigos nas bases de dados PubMed, EBSCOhost e B-On, entre outubro e novembro de 2018, referente ao período de 2013 e 2018, nos idiomas português e inglês. Resultados: foram obtidas 61 referências. Após seleção de acordo com os critérios de inclusão, foram analisados 7 artigos. Conclusões: os diversos estudos enunciam a Comunicação Alternativa e Aumentativa enquanto estratégia potenciadora da comunicação, descrevendo métodos e instrumentos. Não existe consenso relativamente ao instrumento mais eficaz.

Descritores: Comunicação Aumentativa e Alternativa; Respiração Artificial; Cuidados Críticos; Cuidados de Enfermagem; Revisão Scoping.

\section{RESUMEN}

Objetivos: mapear los beneficios de la Comunicación Aumentativa y Alternativa en adultos ventilados en Unidades de Terapia Intensiva e identificar las estrategias utilizadas. Métodos: fue realizada una Scoping Review según el Protocolo Joanna Brigs Institute. La cuestión de investigación fue: “En enfermos adultos ventilados en Unidades de Terapia Intensiva: ¿cuáles los beneficios de la Comunicación Aumentativa y Alternativa?". Una investigación de artículos fue realizada en las bases de datos PubMed, EBSCOhost y B-On, entre octubre y noviembre de 2018, referente al periodo de 2013-2018, en los idiomas portugués e inglés. Resultados: tras la selección según los criterios de inclusión, se obtuvieron 7 referencias. Conclusiones: los diferentes estudios enuncian a Comunicación Aumentativa y Alternativa como estrategia que potencia la comunicación, describiendo los métodos e instrumentos. No existe consenso relativamente al instrumento más eficaz.

Descriptores: Equipos de Comunicación para Personas con Discapacidad; Respiración Artificial; Cuidados Críticos; Atención de Enfermería; Scoping Review. 


\section{INTRODUCTION}

In Intensive Care Units (ICU's), there is a high prevalence of mechanically ventilated patients who, due to their specificity, need special care, particularly in the field of communication where increased difficulties arise. According to the document called "Referral Network for Intensive Care Medicine (Rede de Referenciação de Medicina Intensiva)" of September 2016, in Europe, approximately 990,000 to 1,500,000 patients/year are ventilated in ICU's ${ }^{(1)}$.

ICU's are characterized by the practice of Intensive Medicine that "specifically addresses the prevention, diagnosis and treatment of potentially reversible acute illness situations, in patients who present failure of one or more vital functions, eminent or established"(1). Within this context, critical patients are the target of our care, which is defined as persons "whose life is threatened by failure or imminent failure of one or more vital functions and whose survival depends on advanced means of surveillance, monitoring and therapy"(2).

Communication is an essential element in human interaction and, consequently, in nursing care. Several studies show communication difficulties in patients ventilated in ICU's and, as negative consequences for patients, stress, fear and anger stand out $^{(3)}$ and also the feeling of frustration ${ }^{(4)}$. From the perspective of health professionals, the inability to communicate is associated with feelings of helplessness, frustration and dissatisfaction in the care provided ${ }^{(4)}$. Feelings of hopelessness and loneliness also often occur in this type of patient ${ }^{(5)}$.

The consequences of ineffective communication may be evident in the short or long term ${ }^{(3)}$, and it is also associated with the presence of anxiety and depression after discharge ${ }^{(4)}$.

Augmentative and Alternative Communication (AAC), as a set of tools and strategies to overcome barriers to communication, when verbal is impeded and/or impaired, can be a resource for nurses and patients in the context of the patient ventilated in the ICU.

AAC can take the form of various forms of communication, such as: speech, text, gestures, sign language, symbols, images, electronic speech-generating devices, among others ${ }^{(6)}$. The American Speech-Language-Hearing Association (ASHA) praises the multimodal character of $A A C$, for integrating various modes and forms of communication, both symbolic and non-symbolic.

There is a great diversity of AAC methods and tools, which have to be adapted to the needs and characteristics of the people to whom they are applied. AAC's can be customized according to the specifics of each person and the team of professionals who use them ${ }^{(7-8)}$. The needs of the same patient may vary during hospitalization at ICU, so the same tool can be indicated initially and not later, considering, for instance, the level of sedation to which the person is subject, among other contexts clinical data regarding clinical evolution and treatments ${ }^{(9)}$.

There are factors that can facilitate the use of AAC tools related to the patient, staff, technology and $\operatorname{cost}^{(6)}$. Regarding patients, $A A C$ 's are easier to use if they are intuitive, simple, requiring little training in their use and user-friendly. Professionals showed to be somewhat resistant to change, and reported the need for training in the use of $A A C$ tools, although they value tools that need less training more ${ }^{(6,9)}$. The nurses' experience with $A A C^{\prime} s$ influences the adoption of these tools in their care practices. Regarding technology, there is existence of familiarization with it facilitates, as well as factors related to $\operatorname{cost}^{(3)}$.

Considering the cost-effectiveness, there is no agreement on the preference for high or low technology, nor on the most effective tool $^{(8)}$. There are authors who consider that the combination of both types of technology (high and low) is the best compromise ${ }^{(9)}$.

For an effective communication, the decision process of the AAC tool to be used is favorable to the involvement of the patient, professionals and family ${ }^{(8)}$.

In order to understand the benefits of AAC and its tools used, we considered it pertinent to carry out a Scoping Review on the subject. We formulated the following research question: "In adult patients ventilated in Intensive Care Units, what are the benefits of Augmentative and Alternative Communication?".

\section{OBJECTIVES}

To identify the benefits of AAC in adults ventilated in ICU's and the most used strategies.

\section{METHODS}

\section{Ethical aspects}

The fidelity and veracity of the information contained in the original articles that supported the review were guaranteed, through the rigor of the research methodology, referral, treatment and presentation of data.

\section{Theoretical-methodological framework}

The framework used was The Joanna Briggs Institute, Methodology for JBI Scoping Reviews ${ }^{(10)}$.

\section{Type of study}

This is a Scoping Review, which consists of a systematic, exploratory review, which aims to identify relevant scientific production in a given area.

\section{Methodological procedures}

Initially, an extensive search was carried out at EBSCOhost, PubMed and B-On databases to identify published documents about AAC in patients ventilated in ICU and to identify the words and terms used in the bibliography. Subsequently, a search was carried out in the same databases, using the following terms: "augmentative" AND "alternative communication"; "ventilated patients" AND "intensive care" OR "ICU" OR "critical care" AND benefits. The research was carried out by two researchers simultaneously, between October and November 2018.

\section{Data source}

A search was carried out at EBSCOhost, PubMed and B-On databases, with full text. The selected time interval was from $11 / 02 / 2013$ to $11 / 02 / 2018$. 


\section{Collection and organization of data}

The inclusion criteria established included the acronym PCC were: Participants: ventilated adult patients; Concept: Augmentative and Alternative Communication; Context: Intensive Care Units. Opinion articles, narrative bibliographic reviews, unpublished articles and articles that were not available in full were excluded. Articles of primary investigation and reviews, in English and Portuguese, were considered.

The process of inclusion of the studies is systematized in the PRISMA diagram (Figure 1).

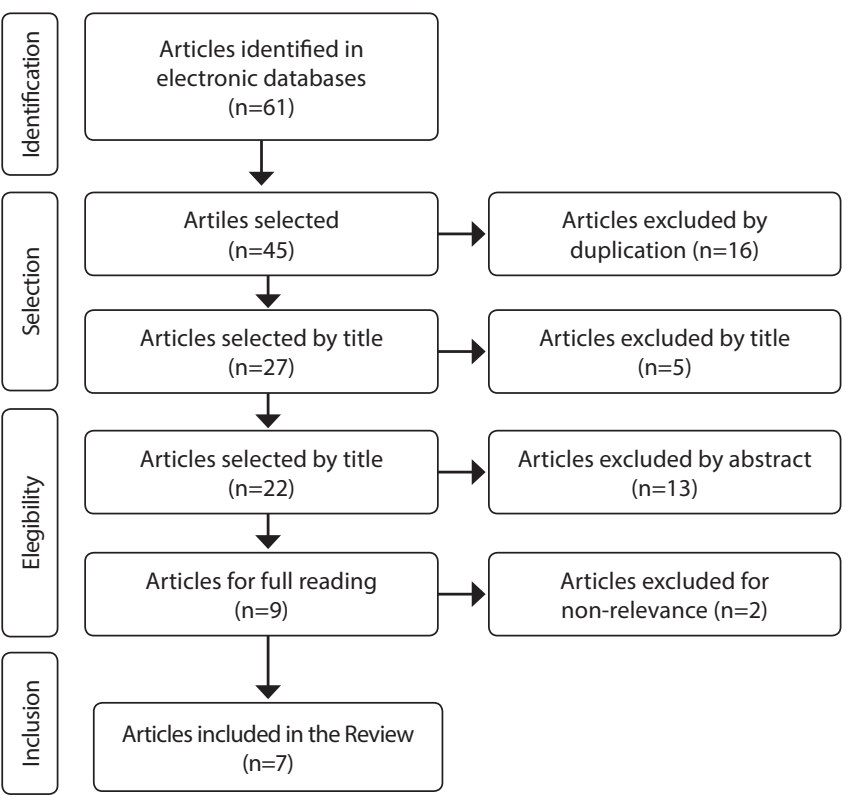

Figure 1 - Process of identification and selection of studies Preferred Reporting Items for Systematic Reviews and Meta-Analyzes (PRISMA) diagram flow

\section{RESULTS}

After assessment and selection of articles, 7 were included in the review. Of these, two are systematic reviews, three are quantitative studies, two are quasi-experimental studies and two are qualitative studies.

The data of the studies are summarized in Chart 1, which contains the titles, type of study/methodology, number of participants, benefits of AAC and methods/AAC tools used.

\section{DISCUSSION}

By reading the articles, we can see that all refer to benefits of $A A C$, although there is none that is cross-sectional to all articles. For a better understanding of the benefits identified in each of the studies, Chart 2 was prepared.

The most identified benefit was the improvement/facilitation of communication among nurses/patients/family members, identified in five of the seven studies (E1, E2, E3, E6 and E7). From the moment patients realize that they can communicate, they can expose their doubts, fears, insecurities and needs ${ }^{(9,11)}$. Improvement of communication allows care adequacy and consequently therapeutic relationship optimization ${ }^{(12)}$.

There are several benefits that were identified in two of the seven articles analyzed, such as increased frequency of communication/interaction among nurses/patients/family members (E1 and E6); decreased stress levels (E5 and E7); more effective and improved pain communication (E1 and E2); increased level of satisfaction (E3 and E5); and increased patient safety (E2 and E4).

Communication breakdowns are the most common cause of incidents and their decrease was identified as a benefit of AAC in an article (E2), thus contributing to the improvement of safety ${ }^{(7)}$.

Through AAC it is possible for patients to express their needs, opinions, fears and concerns, thus reducing the levels of stress and anxiety ${ }^{(3,7-9,11-13)}$.

Chart 1 - Analysis of selected articles, Lisbon. Portugal, 2019

\begin{tabular}{|c|c|c|c|c|c|}
\hline & Title & $\begin{array}{l}\text { Type of study/ } \\
\text { Methodology }\end{array}$ & $\begin{array}{l}\text { Number of } \\
\text { participants }\end{array}$ & Benefits of AAC & $\begin{array}{l}\text { Methods } \\
\text { and AAC tools used }\end{array}$ \\
\hline E1 & $\begin{array}{l}\text { Effect of a multi-level } \\
\text { intervention on nurse- } \\
\text { patient communication } \\
\text { in the intensive care } \\
\text { unit: Results of the } \\
\text { SPEACS trial } \\
\text { (3) }\end{array}$ & $\begin{array}{l}\text { Quasi- } \\
\text { experimental } \\
\text { quantitative }\end{array}$ & $\begin{array}{l}-89 \text { conscious and } \\
\text { intubated patients; } \\
-30 \text { nurses from two } \\
\text { ICU's. }\end{array}$ & $\begin{array}{l}\text { - Increased frequency of } \\
\text { communication and positive } \\
\text { communication behaviors; } \\
\text { - Improved control of pain and } \\
\text { other symptoms; } \\
\text { - Patients and speech therapists } \\
\text { who used more AAC methods } \\
\text { found it less difficult to } \\
\text { communicate. }\end{array}$ & $\begin{array}{l}\text { - Low tech: papers and pens; Board } \\
\text { with alphabet/images/phrases; } \\
\text { notebooks; felt tip pens; } \\
\text { - Supports for the upper limb to } \\
\text { facilitate writing; } \\
\text { - Hearing aids; } \\
\text { - Electronic communication devices, } \\
\text { personalized to each patient. }\end{array}$ \\
\hline E2 & $\begin{array}{l}\text { Communication } \\
\text { aid requirements of } \\
\text { intensive care unit } \\
\text { patients with transient } \\
\text { speech loss }{ }^{(7)}\end{array}$ & $\begin{array}{l}\text { Qualitative } \\
\text { semi- } \\
\text { structured } \\
\text { interview }\end{array}$ & $\begin{array}{l}\text { - } 8 \text { patients; }-4 \text { family } \\
\text { members; } \\
\text { - } 6 \text { employees ( } 2 \text { doctors } \\
\text { and } 4 \text { nurses); } \\
\text { - } 2 \text { speech therapists } \\
\text { - } 30 \text { conscious and } \\
\text { mechanically ventilated } \\
\text { patients. }\end{array}$ & $\begin{array}{l}\text { - Improved communication } \\
\text { between patients and } \\
\text { professionals; } \\
\text { - More effective and improved pain } \\
\text { communication; } \\
\text { - More effective communication } \\
\text { is considered a pillar of patient } \\
\text { safety. }\end{array}$ & - Use of tablet/lpads. \\
\hline
\end{tabular}




\begin{tabular}{|c|c|c|c|c|c|}
\hline & Title & $\begin{array}{l}\text { Type of study/ } \\
\text { Methodology }\end{array}$ & $\begin{array}{c}\text { Number of } \\
\text { participants }\end{array}$ & Benefits of AAC & $\begin{array}{l}\text { Methods } \\
\text { and AAC tools used }\end{array}$ \\
\hline E3 & $\begin{array}{l}\text { Which alternative } \\
\text { communication } \\
\text { methods are effective } \\
\text { for voiceless patients in } \\
\text { Intensive Care Units? A } \\
\text { systematic review }^{(8)}\end{array}$ & $\begin{array}{l}\text { Systematic } \\
\text { review }\end{array}$ & $\begin{array}{l}\text { - Analysis of } 12 \text { studies: } \\
-1,981 \text { patients; } \\
-454 \text { health } \\
\text { professionals. }\end{array}$ & $\begin{array}{l}\text { - AAC strategies are effective } \\
\text { and allow patients to reduce } \\
\text { communication difficulties and } \\
\text { improve their satisfaction. }\end{array}$ & $\begin{array}{l}\text { Low technology AAC tools: } \\
\text { communication boards/images/ } \\
\text { books; board with alphabet; board } \\
\text { with symbols; Paper and pen; } \\
\text { High technology AAC tools: } \\
\text { Speech generator (DynaMyte and } \\
\text { MessageMate"); Speech generator } \\
\text { applications; Eye contolled assistive } \\
\text { technology (TheGrid', Sensory } \\
\text { Software "); LifeVoice Technologies". }\end{array}$ \\
\hline E4 & $\begin{array}{l}\text { Communicating } \\
\text { with conscious and } \\
\text { mechanically ventilated } \\
\text { critically ill patients: a } \\
\text { systematic review }^{(9)}\end{array}$ & $\begin{array}{l}\text { Systematic } \\
\text { review }\end{array}$ & - Analysis of 31 articles. & $\begin{array}{l}\text { - Effective communication with } \\
\text { hospitalized patients is essential } \\
\text { to improve the quality and safety } \\
\text { of healthcare provided. }\end{array}$ & $\begin{array}{l}\text { - Communication boards } \\
\text { and other Low Technologies } \\
\text { equipment; } \\
\text { - High technologies of AAC; } \\
\text { - Other devices: Tracheostomy } \\
\text { tubes (fenestrated) with inflated } \\
\text { cuff (speaking tracheostomy } \\
\text { tube);-Speaking valve; - } \\
\text { Electrolarynx; }\end{array}$ \\
\hline E5 & $\begin{array}{l}\text { Augmented alternative } \\
\text { communication } \\
\text { methods in intubated } \\
\text { COPD patients: Does it } \\
\text { make difference }{ }^{(11)}\end{array}$ & Quantitative & - 60 patients. & $\begin{array}{l}\text { - AAC methods increase the level } \\
\text { of satisfaction and decrease stress } \\
\text { in COPD patients. }\end{array}$ & $\begin{array}{l}\text { - Communication boards; } \\
\text { - Alphabet boards and/or images. }\end{array}$ \\
\hline E6 & $\begin{array}{l}\text { Nurse and patient } \\
\text { interaction behaviors' } \\
\text { effects on quality for } \\
\text { mechanically ventilated } \\
\text { older adults in the } \\
\text { ICU(12) }\end{array}$ & Qualitative & $\begin{array}{l}\text { - } 38 \text { ventilated patients; } \\
\text { - } 24 \text { nurses; } \\
\text { It was performed in an } \\
\text { in a cardio-thoracic ICU. }\end{array}$ & $\begin{array}{l}\text { - The use of AAC strategies was } \\
\text { associated with positive behaviors } \\
\text { on the part of the nursing team, } \\
\text { which: encourage patients to use } \\
\text { the different types of AAC; they are } \\
\text { associated with better pain control, } \\
\text { less need for sedation; they increase } \\
\text { interaction and allow them to } \\
\text { communicate and express needs. }\end{array}$ & $\begin{array}{l}\text { - Non-verbal communication } \\
\text { (nods, gestures, facial expressions, } \\
\text { purposeful look and handshake, } \\
\text { pointing to AAC boards); } \\
\text { - Drawing/writing; } \\
\text { - Trying to spell (lip reading); } \\
\text { - Use of dictating board. }\end{array}$ \\
\hline E7 & $\begin{array}{l}\text { The Effect of Using } \\
\text { Communication } \\
\text { Boards on Ease of } \\
\text { Communication and } \\
\text { Anxiety in Mechanically } \\
\text { Ventilated Conscious } \\
\text { Patients Admitted to } \\
\text { Intensive Care Units }{ }^{(13)}\end{array}$ & $\begin{array}{l}\text { Quasi- } \\
\text { experimental } \\
\text { study }\end{array}$ & & $\begin{array}{l}\text { - The use of communication } \\
\text { aids in conscious and ventilated } \\
\text { patients can facilitate } \\
\text { communication and decrease } \\
\text { stress levels. }\end{array}$ & - Communication boards. \\
\hline
\end{tabular}

Note: AAC - Augmentative and Alternative Communication; COPD - Chronic Obstructive Pulmonary Disease; ICU - Intensive Care Unit.

One of the analyzed articles (E6) identifies the increase in the expression of needs as a benefit of AAC. The favor of pain communication improves therapy adequacy ${ }^{(3)}$, which results in a decrease in pain levels related to the use of AAC (E6); and lower sedation levels (E6). Decrease in pain favors decrease in anxiety ${ }^{(8)}$, corresponding to calmer patients with less need for sedation. The reduction in anxiety levels is also identified as a benefit (E7). Once patients are calmer, they will not need such a high level of seda$\operatorname{tion}^{(9)}$. The use of lower levels of sedation allows less incidence of side effects related to it, namely hemodynamic changes and delirium ${ }^{(3)}$. Ventilatory weaning is also positively influenced by the communication skills between multidisciplinary team and patient, as it allows asking for their collaboration ${ }^{(11)}$.

Increase in the quality of health care provided is highlighted (E4), with emphasis on the reduction of difficulties/breakdowns in communication among nurses/patients/family members (E2) and the development of positive behaviors by the team. This constitutes a stimulus for the use of different types of AAC by patients and nurses (E6), in accordance with the existing literature ${ }^{(3,8,11-12)}$.

In the analyzed articles, thirteen AAC methods/tools were identified. Communication boards (alphabet/images/phrases/symbols) were the most mentioned method, and six of the seven articles mention it (E1, E3, E4, E5, E6 and E7). The second most mentioned method contemplates the use of paper/pen/notebook/writing board (E1, E3, E4, E6 and E7). High-tech tools were mentioned in four articles (E1, E3, E4 and E7), consisting of the use of tablet/ iPad ${ }^{\circ}$, Speech Generator devices (DynaMyte and MessageMate)', Eye Controlled Assistive Technology (TheGrid', Sensory Software") and personalized electronic communication devices. The use of technology to enhance communication is growing and with high cost-benefit. However, its development and impact is still unclear ${ }^{(7-9)}$.

The dictating picture, gestures, facial expressions, lip reading and non-verbal communication were only mentioned in one article (E6). 
Chart 2 - Benefits of AAC described in the analyzed articles. Lisbon, Portugal, 2018

\begin{tabular}{|c|c|c|c|c|c|c|c|}
\hline Benefits of AAC & E1 & E2 & E3 & E4 & E5 & E6 & E7 \\
\hline Improvement/facilitation of communication among nurses/patients/family members & $\mathrm{X}$ & $X$ & $X$ & & & $\mathrm{X}$ & $X$ \\
\hline Increased frequency of communication/interaction among nurses/patients/family members & $\mathrm{X}$ & & & & & $\mathrm{X}$ & \\
\hline Decreased communication breakdowns & & $\mathrm{X}$ & & & & & \\
\hline Permission to express needs & & & & & & $\mathrm{X}$ & \\
\hline More effective and improved pain communication & $\mathrm{X}$ & $\mathrm{X}$ & & & & & \\
\hline Decreased pain levels & & & & & & $\mathrm{X}$ & \\
\hline Decreased anxiety levels & & & & & & & $\mathrm{X}$ \\
\hline Decreased stress levels & & & & & $\mathrm{X}$ & & $\mathrm{X}$ \\
\hline Lower sedation levels & & & & & & $\mathrm{X}$ & \\
\hline Increased level of satisfaction & & & $\mathrm{X}$ & & $X$ & & \\
\hline Increase in the quality of care provided & & & & $X$ & & & \\
\hline Increased patient safety & & $\mathrm{X}$ & & $X$ & & & \\
\hline Generation of positive behaviors in the nursing team/patients & & & & & & $X$ & \\
\hline Encouragement of patients and nurses to use the different types of AAC & & & & & & $\mathrm{X}$ & \\
\hline
\end{tabular}

Nota: CAA - Comunicação Alternativa e Aumentativa.

\section{Study limitations}

We consider that the fact that the research was carries out only in Portuguese and English, and that only articles in full text were considered, may have led to the exclusion of any study potentially relevant to this theme.

\section{Contributions to nursing, health or public policies}

For nursing practice, the benefits are cross-sectional to patients, nurses, family members and other multidisciplinary team members. Therefore, its application translates into an increase in the quality of health care provided to critically ill adult patients ventilated in an ICU.

Several AAC tools have been identified, many of them with low cost and easy access, which can easily be instituted in several ICU's. It is important to implement AAC in care contexts, given its benefits for different users such as patients, family members, nurses and other multidisciplinary team members.

For the development of nursing research, we suggest the development of further studies on AAC application in other contexts, namely in Portugal, since no studies were found in the period included in the study. It is important to know the needs of teams and ventilated patients, relating them to their specific characteristics, such as gender and age to select and use the
AAC tools (high tech and/or low tech) to the patient's needs. In a more comprehensive way, it would be important to assess the AAC tools' cost-benefit, and their organizational impact and on the multidisciplinary team.

\section{CONCLUSIONS}

Communication with patients is essential for adaptation and collaboration during treatment, which motivates health professionals to develop effective communication strategies. Patients in mechanically ventilated intensive care are unable to communicate verbally, which favors the emergence of stress, fear, anger, frustration, and hopelessness, with short, medium and long-term repercussions.

Effective communication establishment can be obtained through AAC, with several benefits for patients, family members and health professionals. There is an improvement in communication among nurses, patients and family members, as well as an increase in frequency. Also important are the improvement of the ability to express pain and its control, the increase in safety and the increase in the level of satisfaction, generating positive behaviors for the patient and the nursing team.

There is no agreement in the literature as to the most effective type or tool, both low tech and high tech, or even the combination of both.

\section{REFERENCES}

1. Paiva JA, Fernandes A, Granja C, Esteves F, Ribeiro J, Nóbrega JJ, et al. Rede de Referenciação de Medicina Intensiva. Redes de Referenciação Hospitalar de Medicina Intensiva. 2016.

2. Ordem dos Enfermeiros. Regulamento de competências específicas do enfermeiro especialista em Enfermagem Médico-Cirúrgica na Área de Enfermagem à Pessoa em Situação Crítica, na área de enfermagem à pessoa em situação paliativa, na área de enfermagem à pessoa em situação crónica [Internet]. Diário da República, 2a série, n¹35 de 16 de julho de 2018[cited 2018 Nov 24]. Available from: https://dre.pt/ application/conteudo/115698617

3. Happ MB, Garrett KL, Tate JA, DiVirgilio D, Houze MP, Demirci JR, et al. Effect of a multi-level intervention on nurse-patient communication in the intensive care unit: Results of the SPEACS trial. Heart Lung. 2014;43(2):89-98. doi: 10.1016/j.hrtlng.2013.11.010 
4. Guttormson JL, Bremer KL, Jones RM. "Not being able to talk was horrid”: A descriptive, correlational study of communication during mechanical ventilation. Intensive Crit Care Nurs. 2015;31(3):179-86. doi: 10.1016/j.iccn.2014.10.007

5. Baumgarten M, Poulsen I. Patients' experiences of being mechanically ventilated in an ICU: a qualitative metasynthesis. Scand J Caring Sci. 2015;29(2):205-14. doi:10.1111/scs.12177

6. International Society for Augmentative and Alternative Communication (ISAAC) [Internet]. 2008 [cited 2018 Nov 24]. Available from: https:// www.isaac-online.org/english/home/

7. Mobasheri MH, King D, Judge S, Arshad F, Larsen M, Safarfashandi Z, et al. Communication aid requirements of intensive care unit patients with transient speech loss. AAC Augment Altern Commun. 2016;32(4):261-71. doi: 10.1080/07434618.2016.1235610

8. Carruthers $\mathrm{H}$, Astin F, Munro W. Which alternative communication methods are effective for voiceless patients in Intensive Care Units? a systematic review. Intensive Crit Care Nurs. 2017;42:88-96. doi: 10.1016/j.iccn.2017.03.003

9. Hoorn S., Elbers PW, Girbes AR, Tuinman PR. Communicating with conscious and mechanically ventilated critically ill patients: a systematic review. Crit Care. 2016;20(1):1-14. doi: 10.1186/s13054-016-1483-2

10. Peters M, Godfrey C, Mclnerney P, Soares C, Khalil H, Parker D. The Joanna Briggs Institute reviewers' manual 2015: methodology for JBI scoping reviews [Internet]. 2015[cited 2018 Sep 21]. Available from: http://joannabriggs.org/assets/docs/sumari/ Reviewers-Manual_Methodology-for-JBI-Scoping-Reviews_2015_v2.pdf

11. El-Soussi AH, Elshafey MM, Othman SY, Abd-Elkader FA. Augmented alternative communication methods in intubated COPD patients: does it make difference. Egypt J Chest Dis Tuberc. 2015;64(1):21-8. doi: 10.1016/j.ejcdt.2014.07.006

12. Nilsen ML, Sereika SM, Hoffman LA, Barnato A, Donovan H, Happ MB. Nurse and Patient Interaction Behaviors' Effects on Nursing Care Quality for Mechanically Ventilated Older Adults in the ICU. Res Gerontol Nurs. 2014;7(3):113-25. doi: 10.3928/19404921-20140127-02

13. Hosseini S-R, Valizad-hasanloei M-A, Feizi A. The effect of using communication boards on ease of communication and anxiety in mechanically ventilated conscious patients admitted to intensive care units. Iran J Nurs Midwifery Res. 2018;23(5):358. doi: 10.4103/ijnmr. IJNMR_68_17 